\title{
Kobiety w życiu i twórczości Alojzego Felińskiego
}

Autorzy prac poświęconych Alojzemu Felińskiemu, sięgając po twórczość krzemieńczanina, analizują niemal każde zdanie napisanej przez niego Barbary Radziwittówny ${ }^{1}$ bądź Hymnu na rocznice ogłoszenia Królestwa Polskiego... ${ }^{2}$ Niestety, w obrębie zainteresowań badawczych nie znajdujemy szerszych omówień relacji Felińskiego z kobietami, mimo że w twórczości dramaturga można odnaleźć wiele fragmentów im poświęconych. W egzemplifikacji artykułu poddane badawczemu oglądowi zostały fragmenty listów, pamiętników oraz wierszy odnoszące się do niewiast, które odegrały ważną rolę w życiu gospodarza Osowy. Należały do nich między innymi: Zofia Załęska, Józefa Omiecińska, Emilia i Tekla z Felińskich czy Helena Felińska.

Celem rozprawy nie jest odkrywanie przed czytelnikiem zupełnie nieznanych utworów czy wydarzeń z biografii Felińskiego. Badawcze spojrzenie stanowi raczej próbę zebrania w jednej publikacji prac autora Radamista i Zenobii poświęconych kobietom, z którymi artysta zetknął się w swoim życiu i wobec których nie pozostawał obojętny, a zarazem ukazanie przedstawiciela klasycyzmu postanisławowskiego w pełniejszym świetle.

Zapewne jedną z pierwszych kobiet, która zrobiła wrażenie na Alojzym Felińskim była Zofia Załęska, przyjaciółka jego siostry - Emilii. Uczucie do tej panny podsycała niewątpliwie admiracja dla mistrza z Genewy - Jana Jakuba Rousseau, pod którego nieukrywanym czarem pozostawał w młodości krzemieńczanin, o czym pisał w wierszu Do Franciszka Wiśniowskiego:

Czy to w miłej postaci malując nam cnotę,

Szczęśliwą wieków złotych uwielbiasz prostotę;

${ }^{*}$ Dr, Uniwersytet Rzeszowski, Instytut Filologii Polskiej, Wydział Filologiczny, Zakład Retoryki i Pragmatyki Komunikacyjnej, al. Rejtana 16 c, 35-959 Rzeszów; e-mail: mpatro@ur.edu.pl

${ }^{1}$ Adresy bibliograficzne prac poświęconych Barbarze Radziwiłtównie podają - Elżbieta Aleksandrowska z zespołem (Bibliografia Literatury Polskiej „Nowy Korbut”, t. 4: Oświecenie, A-H, Państwowy Instytut Wydawniczy, Warszawa 1966, s. 455-456, hasło: Feliński Alojzy) oraz Dobrochna Ratajczakowa (Alojzy Feliński (1771-1820), w: Pisarze polskiego Oświecenia, red. T. Kostkiewiczowa i Z. Goliński, t. 3, Wydawnictwo Naukowe PWN, Warszawa 1996, s. 188-189).

${ }^{2}$ Adresy bibliograficzne prac poświęconych Hymnowi... podaje Krzysztof Bilica - „Boże coś Polskę" Felińskiego-Kaszewskiego. Inspiracje i echa, w: tegoż, Wokół Chopina i Polski. Siedem szkiców, Wydawnictwo Polskie, Wołomin 2005, s. 56-59. 
Czy, depcąc fanatyzmu poczwarę zuchwałą, Zabobonu zasłonę zdzierasz ręką śmiałą; Czy okiem głębokiego natury bogacza Śledzisz do czego ona człowieka przeznacza, A idąc nieomylną drogą doświadczenia, Kształcisz to najpiękniejsze dzieło przyrodzenia;

Czyli też wyższym jeszcze lotem uniesiony Obejmujesz swem piórem ludzi miliony, Wiedziesz ich do wolności, porządku i zgody, Nauczasz, jak się rządzić powinny narody, A mając tylko w celu szczęście twego króla, przepisujesz prawidła prawodawcom świata; wszędzie znajduje w tobie dusza zachwycona, Wymowę Peryklesa i cnotę Platona.

[...]

Przelewasz w moje serce te święte zapały, które boską Julii duszę zachwycały, przenoszę się do wolnej tych kochanków ziemi widzieć ich, naśladować i żyć chciałbym z niemi, A nie mając podobnych im w około siebie, Twórcę tych pięknych marzeń, czczę jak bóstwo ciebie.

$[\ldots]$

Chcę tylko waszem światłem mój rozum prostować,

Czytać Was, czuć i wielbić, a nie naśladować;

$[\ldots]^{3}$

W powyżej cytowanym fragmencie wiersza można dostrzec zachwyt poety nad poglądami francuskiego myśliciela. Zaiste Feliński nawiązał w swym utworze do problematyki społecznej, jaką Rousseau zawarł w rozprawkach na temat odrodzenia nauk i sztuk oraz nierówności między ludźmi. Krzemieńczanin wydaje się popierać koncepcję „człowieka natury”, który we własnym wnętrzu odnajduje zasady postępowania, a nieskrępowany z innymi więzami społecznymi, może stać się dobry, szczęśliwy i wolny. Ponadto Feliński wspomniał społeczno-ustrojową koncepcję autora Umowy społecznej. Powołując się z kolei na „boską Julię", manifestował niejako znaczenie i wyższość uczucia nad dzielącymi ludzi różnicami społecznymi, pośrednio także podkreślał związek człowieka z przyrodą czy walory wiejskiego życia. Akcentował zatem emocjonalne czynniki ludzkiej osobowości.

${ }^{3}$ A. Feliński, Do Franciszka Wiśniowskiego, w: tegoż, Pisma i listy Alojzego Felińskiego przepisane z jego autografów, rkps Ossol. 2097/I, k. 6. 
Odnosząc się do fascynacji Felińskiego potęgą geniuszu autora Nowej Heloizy, Klemens Kantecki z kolei podkreślał, że krzemieńczanin, pozostając „pod świeżym wrażeniem czaru słowa i siły dowodzeń, nie umiał się zdobyć na opozycję, nie zdołał odkryć w genewskim pustelniku stron ujemnych, dążności dla społeczeństwa szkodliwych. Widzi on w nim tylko zacnego obywatela, pogromcę tyranii, mianuje go «bóstwem serc czułych i cnotliwych»"'.

Śledzenie historii rozwoju uczuć pomiędzy Julią a Saint Preux, przynajmniej pośrednio, mogło zaowocować przyśpieszeniem bicia serca Felińskiego dla, wspomnianej wcześniej, Zofii Załęskiej. O nadziei jej poślubienia nie omieszkał poeta wspomnieć także w cytowanym już wierszu do przyjaciela, Franciszka Wiśniowskiego:

Oby ta, w której ręku moje przeznaczenie Która wznieciła we mnie te czyste płomienie,

Ten tak rzadki miłości szczerej ogień boski,

Ta, dla której jedynie przyszłość mi jest miła,

Oby Zosia mojego szczęścia dopełniła!

Bez żalu sobie spomnę upłynnione lata,

Zabawy, spaniałości i rozkosze świata,

A z Zosią, z przyjaciółmi i z siostrą kochaną

Dni się życia mojego najmilszemi staną ${ }^{5}$.

Pannę Załęską i przyszłego twórcę tragedii łączyło nie tylko młodzieńcze, pełne słodkich szeptów i czułych gestów uczucie, ale także powiązały ich wspólne fascynacje literackie oraz intelektualna dojrzałość. Wzajemne relacje pary nasuwają skojarzenia z młodzieńczą fascynacją Adama Mickiewicza Marylą Wereszczakówną, z tą różnicą, że przy braku zgody krewnych Zosi na ślub z Felińskim, poza kilkoma pełnymi łez miesiącami, gospodarz Osowy dosyć szybko odzyskał równowagę ciała i umysłu, a chłopięce zadurzenie nie miało wpływu na jego twórczość, serce z kolei w stosunkowo niedługim czasie skierował w stronę innej, bardziej osiągalnej panny.

Przypomnijmy jednak, że małżeństwu Alojzego z Zofią sprzeciwił się krewny Załęskich - ks. Podhorodeński, któremu „nie przypad[ły] do myśli wyobrażeni[a] religijne Felińskiego, jakkolwiek nie rzucił on [Feliński - M. P.K.] wyraźnie rękawicy wyznaniu i wierze ojców, są podejrzane i zdają się trącić nowomodną filozofią" . W cytowanym powyżej wierszu do Wiśniowskiego odnajdujemy bowiem hołd złożony przez krzemieńczanina autorowi Dziewicy orleańskiej:

${ }^{4}$ K. P. Kantecki, Dwaj krzemieńczanie, cz. 1: Alojzy Feliński, Gubrynowicz i Schmidt, Lwów 1879, s. 66.

${ }^{5}$ A. Feliński, Do Franciszka Wiśniowskiego..., k. 6.

${ }^{6}$ E. Felińska, Pamiętniki z życia, t. 1, seria 2, Józef Zawadzki, Wilno 1858, s. 246. 
Ty co wyższy nad zawiść i prześladowanie

Rozciągnąłeś najszerzej nauk panowanie,

Wieczny gustu, dowcipu i pisania wzorze

Brutusa, Mahometa, Zairy autorze! ${ }^{7}$

Poeta powołuje się przede wszystkim na tragedie autorstwa François Marie Aroueta, w których idee przewodnie wolterianizmu znalazły dobitne sformułowanie. Odzwierciedlały one, podobnie jak inne jego pisma, charakterystyczną postawę francuskiego autora, która przejawiała się zarówno w bezwzględnym krytycyzmie wobec tradycyjnych autorytetów (w zakresie nauki, polityki czy moralności), jak i poprzez artykułowanie niezależności człowieka (ufność w siłę ludzkiego rozumu jako samodzielnej władzy poznawczej). Prace Woltera były ponadto manifestacją społecznej tolerancji dla różnych przekonań i poglądów.

Na temat światopoglądu i przekonań Felińskiego będących wynikiem czytania dzieł myśliciela z Ferney pisał także w Pamiętnikach Kajetan Koźmian, który - wspominając Emilię Potocką - stwierdził, że ta była wychowana ,przez brata poetę, sceptyka i wolterzystę [...]"8. Ów wolterianizm miał sprawić, że ostatecznie ojciec panny Zofii - mimo protestów jej, dziedzica Osowy i jego przyjaciół z Tadeuszem Czackim na czele - nie wyraził zgody na to małżeństwo. Decyzję krewnych panny Załęskiej należy wytłumaczyć zapewne obawami przed oddziaływaniem obecnych w pismach Woltera koncepcji filozoficznych, które upowszechniały deizm.

Wspomnienie młodzieńczej miłości, a przede wszystkim wyobrażenie ukochanej w roli żony, matki i obywatelki odnajdziemy w wierszu Do Sofii, w którym poeta prezentuje się jako admirator cnót zarówno Zofii, jak i jej małżonka, Litwińskiego:

Sofijo kto cię z mężem z dziećmi widział razem

Poznał że szczęścia tego dom wasz jest obrazem.

Lecz do rymów Tompsona9 ten dodatek zrobię,

Którego słuszność każdy Polak przyzna,

Że w twym mężu dobrego syna ma ojczyzna

A nieszczęśliwi mają matkę $\mathrm{w}$ tobie ${ }^{10}$.

${ }^{7}$ A. Feliński, Do Franciszka Wiśniowskiego..., k. 5.

${ }^{8}$ K. Koźmian, Pamiętniki, przedm. A. Kopacz, wstęp i koment. J. Willaume, wstęp edytorski, ustalenie tekstu w oparciu o autograf oraz koment. filologiczny M. Kaczmarek, K. Pecold, Zakład Narodowy im. Ossolińskich, Wrocław 1972, t. 3, s. 443.

${ }^{9}$ Fragment Pór roku J. Thomsona pt. Szczéśliwe matżeństwo przełożył poeta w 1794 r. (A. Feliński, Pisma własne i przektadania wierszem, t. 1, Drukarnia Rządowa, Warszawa 1816, s. 369-371).

${ }^{10}$ A. Feliński, Do Sofii, w: Pisma i listy Alojzego Felińskiego przepisane z jego autografów, rkps Ossol. 2097/I, k. 14-15. 
Feliński tym samym odmalowuje portret ziemianki pierwszej połowy XIX wieku, na której spoczywał obowiązek zarządzania gospodarstwem domowym, wychowania dzieci, a także dbałość o edukację swoich pociech czy kultywowanie zwyczajów rodzinnych, świątecznych i sąsiedzkich ${ }^{11}$.

Do wspomnienia młodzieńczego uczucia powróci krzemieńczanin również w liście do Michała Wyszkowskiego:

Owa blondyneczka Z..., którą jeśli pamiętasz, będąc w tych stronach widziałeś, ułożywszy się na bardzo wyborną panienkę, była celem mych życzeń, kochałem ją i byłem kochany; ale familia i inni jeszcze, tak mocne mi postawili zawady, że je ani Czacki, ani żaden z przyjaciół moich przełamać nie mógł. Zalewałem się łzami, ale to wszystko nic nie pomogło. Przepędziłem w takim stanie kilka miesięcy, nie znajdując wiele słodyczy w życiu. Ale, że jak Wolter mówi: „Człowiek trapi się i płacze jak może najmniej”, i ja się pocieszyłem nareszcie $^{12}$. (28 marca 1800 roku z Helenówki, s. 396)

Pocieszenie dramaturg miał odnaleźć kilka lat później w ramionach żony, Józefy Omiecińskiej, którą poślubił raczej z rozsądku, chociaż pewne jest, że przyczyną ślubu nie były spekulacje majątkowe. W chwili ożenku panna „Kijowianeczka" miała skromny posag, który z czasem powiększył się jednak o dwie sukcesje. Nie zaliczała się ponadto do kobiet o szczególnej urodzie, była raczej skromna i łagodna, a zatem wyróżniały ją te walory, które pozwalały zapewnić ciche szczęście w małżeństwie. O małżonce autor Barbary... pisał:

Przyjechawszy na ową sprawę do Żytomierza, w okolicach tutejszych poznałem jedną Kijowianeczkę, panienkę przyjemną, skromną, czułą, charakteru najłagodniejszego, humoru jednostajnego. Podobałem ją sobie, i wkrótce miałem szczęście jej się podobać. Od czterech tygodni jest już moją żoną, i od czterech tygodni jestem zupełnie szczęśliwy... Ma lat siedemnaście; majątek jej wyrówna memu, nigdym więcej nie żądał. Ale podobno już dosyć o niej, wiem że pochwały czteroniedzielnego męża są trochę podejrzane, lecz ja spodziewam się za kilka lat, toż samo powtórzyć. Teraz dodam tylko jej imię i nazwisko. Zwała się Omiecińska, imię ma Józefa. Patrz tedy z nas trzech, ja, który nie byłem

${ }^{11}$ Na temat wizerunku Polki w 1. poł. XIX w., opierając się na ówczesnych poradnikach, cenne uwagi poczyniła Małgorzata Stawiak-Ososińska - Ponętna, uległa, akuratna ... Ideat $i$ wizerunek kobiety polskiej pierwszej połowy XIX wieku (w świetle ówczesnych poradników), Wydawnictwo Impuls, Kraków 2010.

${ }^{12}$ Listy poety przywoływane są w rozprawie według wydania: K. z Tańskich Hoffmanowa, Dzieła. Wydanie nowe z dodaniem życiorysu i objaśnień, red. N. Żmichowska, t. 6, Spółka Wydawnicza Księgarzy, Warszawa 1875. W tekście głównym odnotowano numery stron, z których przywoływane są fragmenty listów. Częściowo zmodernizowałam pisownię i przestankowanie, przy zachowaniu większości cech językowych i oboczności oryginału. 
najmniej gorliwym deklamatorem przeciw ożenieniu, najpierwej żonkisiem zostałem. (28 marca 1800 roku z Helenówki, s. 397)

Informacje na temat obu sympatii dyrektora krzemienieckiego Liceum odnotowała także w swoim pamiętniku jego bratowa, Ewa Felińska, która wspominała:

Z dawną kochanką bez wątpienia miał więcej stosowności w usposobieniach umysłowych. Zosia Załęska miała rozum silny sam z siebie i wyrobiony czytaniem, tłumaczyła myśli swoje dobrze, pisała powabnie, czuła, i ocenić umiała piękności literackie. Pod tym względem miała wiele wyższości nad żoną Alojzego, ale co się tyczy innych przymiotów, dotykających obowiązków żony i gospodyni domu, w tych wszystkich Alojzowa otrzymywała pierwszeństwo. Co do różnicy charakterów, Zosi charakter miał więcej energii, Alojzowej więcej słodyczy. W postępowaniu Zosia rządziła się rozumem własnym, którego miała dużo, Alojzowa ulegała tym, których uznawała prawo nad sobą; a najwyższym prawem był dla niej katechizm, którego w dzieciństwie się nauczyła ${ }^{13}$.

Józefa Omiecińska, chociaż nie była z pewnością dla Felińskiego partnerką intelektualną, to jednak z pasją i zaangażowaniem potrafiła prowadzić gospodarstwo domowe. Cechowała ją troska o dom, męża i dwójkę dzieci. Sama zajmowała się swoim potomstwem, a kiedy rodzinne posiadłości Felińskich nawiedzali goście, podejmowała ich z życzliwością. Ewa Felińska wspominała na przykład:

\begin{abstract}
Alojzowa [...], która wstawała rano, zaspokoiwszy potrzeby swego gospodarstwa przyszła dać dobry dzień matce i nam wszystkim, i zapowiedziała, że będzie czekać nas wszystkich ze śniadaniem na dziesiątą godzinę; jakoż dzieląc czas między rozmowę i krzątaniny, ledwie zdołaliśmy skończyć dzienne ubranie, kiedy wezwano nas na śniadanie. [...] Zastaliśmy stół zastawiony kilku potrawami [...] Śniadanie nie przeszkadzało rozmowie, która poszła tak łatwo, tak swobodnie, że nie upłynęło więcej godziny, a już byliśmy zaznajomieni, spoufaleni tak, jak gdybyśmy od dzieciństwa żyli razem ${ }^{14}$.
\end{abstract}

Mogła zatem Józefa Felińska zachwycać szczerością i dbałością o domowe szczęście, ponadto także jej pożycie z poetą należało do udanych i nigdy nie zostało zakłócone przez wzajemne konflikty czy antagonizmy ${ }^{15}$. Feliński pisał bowiem do Wyszkowskiego, że żona czyni go co dzień szczęśliwszym, a pośród zacisza domowego sam może kosztować szczęścia, do jakiego inni tylko mogą wzdychać (list z 13 marca 1801 roku z Horochowa, s. 397). Poeta prezentuje mał-

\footnotetext{
${ }^{13}$ E. Felińska, dz. cyt., s. 248

${ }^{14}$ Tamże, s. 205-206.

${ }^{15}$ Por. tamże, s. 232.
} 
żonkę zgodnie z konwencją obowiązującą w poezji ziemiańskiej, jako twórczynię domowego ogniska, kobietę sprawująca opiekę nad rodziną. Można stwierdzić, że gospodyni Osowy utwierdza patronat Hestii nad dworkową (osowską) harmonią istnienia. W listach pisanych do Wyszkowskiego Feliński powiadamia adresata o szczęściu, którego doświadcza, głównie za sprawą idealnej i cnotliwej kobiety troszczącej się o dom i najbliższych. Taki obraz żony znajduje źródła w etyce Arystotelesa i jej chrześcijańskiej adaptacji, a z punktu widzenia polskiej tradycji literackiej - przede wszystkim w Żywocie człowieka poczciwego Mikołaja Reja, Pisaniu statecznej i pobożnej żony Erazma Otwinowskiego czy Pieśni Jana Kochanowskiego $^{16}$.

Na marginesie można jeszcze dodać, że pani Józefa po śmierci Felińskiego godnie zadbała o spuściznę męża, przygotowując wraz z Gustawem Olizarem zbiorowe wydanie dzieł autora Barbary Radziwiłlówny ${ }^{17}$, wznosząc dramaturgowi ,pomnik trwalszy od spiżu” i granitu ${ }^{18}$.

Poza sympatią z lat młodości oraz żoną, szczególny rodzaj więzi łączył Felińskiego z jego siostrą, Emilią z Felińskich Potocką ${ }^{19}$. W jednym ze swoich listów dramaturg stwierdzał:

Siostra moja także nie wiem, jeśli była zupełnie nieczułą na tyle pochlebnych dla niej doucerów (ale za cóż po polsku nie napisać słodyczy)... Masz jeszcze kawał jej tłumaczenia z Britannika. Sądź go i krytykuj, jak Ci się podoba. [...]

${ }^{16}$ Zob. A. Karpiński, Staropolska poezja ideałów ziemiańskich. Próba przekroju, Zakład Narodowy im. Ossolińskich, Wrocław 1983, s. 61. Studia Staropolskie, t. 49 oraz M. Patro-Kucab, Osowa Alojzego Felińskiego. Kreacja ziemiańskiego pejzażu w listach poety skierowanych do Michała Wyszkowskiego, w: Antropologia krajobrazu: obraz-zmysty-pamięć, red. B. Frydryczak i M. Ciesielski, Wydawnictwo Poznańskiego Towarzystwa Przyjaciół Nauk, Poznań 2014, s. 325. Seria Krajobrazy, t. 5

${ }^{17}$ A. Feliński, Pisma własne i przekładania wierszem, t. 2, Drukarnia Natana Glücksberga księgarza i typografa Królewskiego Uniwersytetu, Warszawa 1816-1821.

${ }^{18}$ Zob. na ten temat także uwagi Michała Wyszkowskiego - Przymówienie się Referendarza Stanu Michała Wyszkowskiego na posiedzeniu publicznem dnia 3 Maja 1820 r. przed rozpoczęciem czytania przez Niego wyimków z „Poezyi” zmarłego niedawno Kolegi Alojzego Felińskiego, „Roczniki Towarzystwa Królewskiego Warszawskiego Przyjaciół Nauk” 1821, t. 14, s. 125 oraz W. Turski, Do cieniów Alojzego Felińskiego, „Weteran Poznański” 1825, nr 1 (luty), s. 57-61. O wspólnej pracy Olizara i Felińskiej nad zebraniem i wydaniem spuścizny po autorze Barbary... pisze także W. Piotrowski (Gustaw Olizar (1798-1865), w: Krzemieniec. Ateny Juliusza Słowackiego, red. S. Makowski, Wydawnictwo Biblioteki Narodowej, Warszawa 2004, s. 335-336 oraz Życie umysłowe Krzemieńca 1805-1832, Naukowe Wydawnictwo Piotrkowskie przy Filii Akademii Świętokrzyskiej, Piotrków Trybunalski 2005, s. 159).

${ }^{19} \mathrm{Na}$ temat siostry Felińskiego pisałam także w artykule pt. Kreacja wołyńsko-poleskiej przestrzeni (na podstawie listów Alojzego Felińskiego do przyjaciela, Michała Wyszkowskiego), w: Język polski i polonistyka w Europie Wschodniej: przeszłość $i$ współczesność, Praca zbiorowa z okazji dziesięciolecia Katedry Filologii Polskiej Narodowego Uniwersytetu Lwowskiego im. Iwana Franki, red. I. Bundza, J. Kowalewski, A. Krawczuk, O. Śliwiński, Firma „INKOS”, Kijów 2015, s. 188-191. 
Patrz, jak to dobrze mieć siostrę co rymuje? wy mi będziecie przysyłać swoje wiersze, a ja wam wiersze mojej siostry. Żartujcie z niej jak chcecie, ja jednak rozumiem, że jeżeli zawsze będzie w niej trwała taka chęć jak teraz, zasłużenia sobie na zawsze pochwały, niedługo będziecie z niej żartować... Nie uwierzysz jakem z niej kontent, od czasu jak was poznała, coraz więcej pracuje i coraz lepiej. Proszę was bardzo, żebyście w pierwszym liście do mnie dali swoje zdanie o jej wierszach, i wytknęli jeżeli nie wszystkie, znaczną przynajmniej część błędów. Czeka ona tego wyroku z największą niecierpliwością.

(list z 15 kwietnia 1795 roku z Wojutyna, s. 392-393)

Należy przypomnieć, że córka Rozalii Felińskiej otrzymała staranne wykształcenie, jakie było wymagane w wykwintnym towarzystwie. Dziewczyna odbyła edukację we lwowskiej pensji panien prezentek Wizytek (instytucji, która cieszyła się na owe czasy doskonałą reputacją, a naukę w niej odbywały uczennice pochodzące z najbardziej znamienitych domów ${ }^{20}$. Aparycję i usposobienie siostry Felińskiego z czasów szkolnych przedstawia Ewa Felińska:

Pojęcie żywe łatwo przyswajało wiadomości, dusza czuła i poetyczna odgadywała wymagania sztuki, a smak wrodzony piętnował pięknem każdą rzecz, której się dotknęła. [...] Według zdania osób, które ją znały, była niepospolicie piękną, a co więcej, że ta piękność nie była martwą, ale wewnętrzne życie nadawało jej urok nieopisany. Obdarzona była wielkim zasobem czułości i wyobraźni, ale ta czułość nie brała za przedmiot świata urojonego, jak to często bywa, ani siebie jedną miała na celu, tylko się rozlewało na wszystkich, co się do niej zbliżali. Zawsze gotowa była rozdzielić się i uczuciem, i mieniem z każdym, co był pod naciskiem jakiejkolwiek potrzeby, zawsze usposobioną się czuła do ofiary nie oglądając się nawet na przestrogi roztropności ${ }^{21}$.

Nie dziwi zatem fakt, że Alojzy Feliński w swoich listach pisze o siostrze z uznaniem. Jego zachwyt wzbudza jednak nie nieprzeciętna uroda kobiety, lecz jej poetycki talent (uwidacznia się zaangażowanie dramaturga w sprawy literackiej krytyki poetyckich prób podejmowanych przez Emilię; pisze w liście o przekładzie Brytannika Jeana Racine’a, którego krytycznego osądu od Wyszkowskiego Feliński niemal się domaga). Poznajemy zatem siostrę poety jako osobę niezwykle mu bliską, uznaje on ją bowiem za swoją bratnią duszę. Młoda kobieta była niechętna prozaicznym zajęciom, pasjonowały ją przede wszystkim muzyka i literatura, dlatego wspólnie z bratem nie tylko czytała, ale także pisała wiersze, z którymi ,nigdy nie miała pretensji występować do druku, pisała [je - przyp. M.P. K.] jedynie dla dogodzenia

${ }^{20} \mathrm{Na}$ temat edukacji Polek w 1. poł. XIX w. zob. M. Stawiak-Ososińska, dz. cyt., s. 53-74.

${ }^{21}$ E. Felińska, dz. cyt., s. 347-348. 
sercu"22. Rodzeństwo wykazywało więc podobieństwo usposobienia, a ich szczera przyjaźń nawiązała się po zamieszkaniu dramaturga u matki w Wojutynie.

Na temat ,braterstwa uczuć i ducha” pomiędzy rodzeństwem wypowiedział się także Samuel Orgelbrand:

Z upadkiem sprawy narodowej osiadł [Feliński - przyp. M.P. K.] w Wojutynie, poświęcając się wyłącznie podeszłej matce, niedorosłemu rodzeństwu oraz pracom gospodarskim. Ciche życie domowe tem więcej miało dla niego powabów, że w ukochanej siostrze swojej Emilii znalazł więcej niżeli braterstwo krwi, bo braterstwo uczuć i ducha. Emilia wiele okazywała daru do poezji: tłumaczenie kantaty Russa, p. n. Cyrce, drukowana w „Dzienniku Wileńskim” w 1806 roku $^{23}$ zjednało sławę osiemnastoletniej poetce. Feliński zajął się jej kształceniem literackim ${ }^{24}$.

Do wątku związanego z najstarszą siostrą autor Barbary... powróci po raz kolejny kilka lat później, by powiadomić swojego przyjaciela o jej zamążpójściu:

W tym samym czasie kiedym ja dostał żony, Emilka dostała męża. Jest to syn jedynak, Potockiego podczaszego, bardzo poczciwego staruszka, który jest rodem z stron waszych. Chłopiec ten mający dopiero lat 23, ma najlepsze serce, i zdaje się rzetelnie być przywiązany do siostry mojej.

(28 marca 1800 roku z Helenówki, s. 397)

Przypomnijmy, że o rękę Emilii Felińskiej starało się wielu adoratorów. Pośród nich należy wskazać z pewnością pułkownika księcia d’Anhalt, Franciszka Wiśniowskiego (Wiszniowskiego) ${ }^{25}$ i Ignacego Potockiego ${ }^{26}$. Epistolograf w swoim liście wymienia tego ostatniego, który został mężem jego siostry. Para poznała się w Klepaczach (powiat ostrogski), dokąd każdego roku w okresie letnim wyjeżdżała z rodziną Rozalia Felińska w celu dopilnowania tutejszego majątku. Potoccy mieszkali niedaleko od Klepacz, w Chorostku, a ojciec Ignacego był dobrym

${ }^{22}$ Tamże, s. 350.

${ }^{23}$ Tekst do druku („Dziennik Wileński” 1806, t. 3, nr 7, s. 95) przekazała Zofia z Załęskich Litwińska. Zob. E. Felińska, dz. cyt., s. 350. Kantatę w całości zamieszcza też w swojej pracy o sławnych Polkach Jan Sowiński (tenże, O uczonych Polkach, w księgarniach Natana Glücksberga. Księgarza i typografa Uniwersytetu Warszawskiego i Liceum Wołyńskiego, Warszawa-Krzemieniec 1821, s. 159-162).

${ }^{24}$ S. Orgelbrand, Feliński Alojzy, w: tegoż, Encyklopedia powszechna, t. 8, nakład, druk i własność Samuela Orgelbranda księgarza i typografa, Warszawa 1861, s. 727-728.

${ }^{25}$ Formę nazwiska podaję za: E. Aleksandrowska z zespołem, Bibliografia Literatury Polskiej „Nowy Korbut”, t. 6, cz. 1: Oświecenie, $P-\dot{Z}$, Państwowy Instytut Wydawniczy, Warszawa 1970, s. 434, hasło: Wiśniowski Franciszek Salezy.

${ }^{26}$ E. Felińska, dz. cyt., s. 348 i nn. 
znajomym i przyjacielem matki Alojzego. Do spotkań młodych dochodziło także w Anapolu (majątku księcia Stanisława Jabłonowskiego) oraz w Krzywinie (należącym do księcia Maksymiliana Jabłonowskiego). Siostra Felińskiego chętnie uczestniczyła w odbywających się w okolicznych posiadłościach balach i spotkaniach, a towarzyszył jej młody Potocki, co poświadcza Ewa Felińska:

[...] był nieodstępnym w tych wszystkich zabawach; Emilka miała w nim zawsze i tancerza i kawalera starającego się podobać różnemi sposobami, gotowego na jej skinienia. Rola jego nie była dwuznaczną: młody, żywy, zakochany, wcale się $\mathrm{z}$ tem nie taił, że jest nią zajęty. Emilce te starania w podobaniu się Potockiego, widno że nie były nieprzyjemne, bo nie chciała ani ich uniknąć, ani odsunąć ich od siebie; jakoż Potocki zawsze się znajdował na jej drodze, robiąc jakąś przyjemność, urządzając niespodzianki, do czego ojciec szczerze dopomaga ${ }^{27}$.

W związku z tym, że adorator nie odstępował młodej poetki niemal na krok, ostatecznie, mimo przeciwności, za jakie można uznać poczucie obowiązku wobec Wiśniowskiego ${ }^{28}$, wyszła ona za mąż za Potockiego, a ich pożycie małżeńskie początkowo układało się w miarę pomyślnie dla obojga, co znajduje odzwierciedlenie w listach Felińskiego:

Donoszę Ci krótko, że Emilka przed trzema tygodniami powiła syna; [...] Przekonywam się coraz bardziej, że wśród osób nam miłych i zacisza domowego, można kosztować takiego szczęścia, do jakiego tylko wzdychać teraz możemy.

(13 marca 1801 roku z Horochowa, s. 397-398)

Wymieniony przez epistolografa syn Emilii Potockiej to Albert (Wojciech) Szeliga hrabia Potocki, urodzony w 1801 roku, a zatem w trzecim roku małżeństwa $^{29}$. Jednak już wkrótce poczucie szczęśliwej egzystencji rodziny Potockich, na skutek różnorodnych zrządzeń losu, zostaje zachwiane.

27 Tamże, s. 355 .

${ }^{28}$ Franciszek Wiśniowski był przyjacielem Alojzego Felińskiego. Jego związkowi z siostrą poety, ze względu na sytuację materialną kandydata na męża, była przeciwna Tomaszowa Felińska (Wiśniowski był właścicielem części wsi na Polesiu, z której miał wyposażyć kilka sióstr). Na temat tego związku zob. wspomnienia E. Felińskiej (tamże, s. 351-368). Por. też biogram Franciszka Wiśniowskiego zawarty w publikacji - S. Orgelbrand, Encyklopedia..., t. 27, Warszawa 1876, s. 264.

${ }^{29}$ Kilkanaście lat później na karty swojego utworu pt. Rozmowa w Zaciszy z powodu listu Pana Szczeropolskiego wprowadzi go Alojzy Feliński (zob. na temat tego utworu pracę - M. Patro-Kucab, Ciag dalszy sporu o ,intruza gdańskiego”, czyli Alojzy Feliński ripostuje Janowi Śniadeckiemu (Rozmowa w Zaciszy z powodu listu Pana Szczeropolskiego), w: Kultura mówienia dawniej i dziś, red. M. Kułakowska, A. Myszka, Wydawnictwo Uniwersytetu Rzeszowskiego, Rzeszów 2014, s. 101-111. O Emilii Potockiej - matce zob. pracę - S. P. Dąbrowski, Rodzinne i środowiskowe uwarunkowania natury oraz losów Alberta Potockiego w świetle przekazów pamiętnikarskich, w: 
Przede wszystkim warto przypomnieć, że małżeństwo Emilii Potockiej od dawna nie należało do udanych. Kiedy ze strony Potockiego minęło pierwsze zauroczenie młodą małżonką, siostra Felińskiego spostrzegła - co podkreśla bratowa rodzeństwa -

że nie jest już dla męża tem, co była wprzódy, a że ich nawyknienia, upodobania nie zbiegały się z sobą w żadnym punkcie, żaden ściślejszy związek nie zastąpił miejsca ostygających zapałów miłości. Młody mąż potrzebował świata, potrzebował świeżych wrażeń, gonił za niemi; [...] Emilka [...], widząc się już niepotrzebną mężowi, którego wybrała, uczuła się nieszczęśliwą ${ }^{30}$.

Dodatkowo ciosem dla siostry poety okazała się wiadomość o chorobie (silnej malignie) Wiśniowskiego. Wówczas targały kobietą wyrzuty sumienia i zwątlało się jej zdrowie. Matka Alberta Szeligi zmarła na suchoty, bowiem zabiegi zmierzające do wyleczenia żony hrabiego Potockiego okazały się nieskuteczne, na co zwraca uwagę autor Barbary... w liście skierowanym do przyjaciela:

[...] Tę siostrę, którąś ty znał, tak kochaną ode mnie i tak godną kochania, pełną cnót, wdzięków, talentów, w samym kwiecie wieku, matkę trzyletniego synka, Emilkę kochaną straciłem. Pamięć jej, może i tobie kilka łez wyciśnie. Ach! czemuż ich nie możesz pomięszać z mojemi... Emilka... Emilka już nie żyje! (25 maja 1805 roku z Osowy, s. 399)

Przypomnijmy, że nagrobek Emilii Potockiej poświęcił również dawny jej wielbiciel - Wiśniowski (który zaledwie rok po śmierci ukochanej także pożegnał się ze światem):

W godniejsze ciebie strony uniesiona,

Jeżeli z wiecznej spokojności łona,

Wzrok się twój kiedy zatrzyma,

Gdzieś była, gdzie cię już nie ma.

Niech ta czułości pamiątka nietrwała,

Którą twe cienie przyjaźń uczcić chciała,

I łzy jej na twym wylewane grobie,

Jeszcze te miejsce zrobią miłe tobie ${ }^{31}$.

Sarmackie theatrum VII. W kręgu rodziny i prywatności, red. M. Jarczykowa, R. Ryba, Wydawnictwo Uniwersytetu Śląskiego, Katowice 2014, s. 238, 246-248.

${ }^{30}$ E. Felińska, dz. cyt., s. 368.

${ }^{31}$ Tamże, s. 371-372. 
Reasumując, należy podkreślić, że tłumacz Ziemianina ... za sprawą swej korespondencji przybliża postać Emilii Potockiej, którą charakteryzuje jako kobietę pełną cnót, a nade wszystko niewiastę uroczą i obdarzoną poetyckim talentem. Feliński ponadto informuje adresata swych listów o niezwykłej więzi pomiędzy rodzeństwem, odkrywa sekrety serca i koleje losów siostry. Do siostrzanego wątku powróci jeszcze w jednym z listów w roku 1808:

Ja niepocieszony po stracie Emilki i Wiszniowskiego, prowadzę życie jednostajne, i skądinąd dosyć przyjemne, poświęcając mój czas familii, przyjaciołom i zatrudnieniom domowym. Bawi u mnie najlepsza matka i siostra Tekla, która mi przypomina Emilkę. Gdybyś z bliska patrzył na nas, zachęciłbyś się pewnie do ożenienia.

(15 lipca 1808 roku z Osowy, s. 400)

Tym razem gospodarz Osowy wskazuje na swoją młodszą siostrę Teklę Felińską, która w pewnym sensie wypełniła pustkę po odejściu Emilki. Młodszej siostrze $^{32}$ epistolograf nie poświęca jednak tak wiele uwagi.

Ostatnią, a zarazem najmłodszą z kobiet, która zajmuje istotne miejsce w biografii i twórczości autora Radamista i Zenobii, jest Helenka Felińska, córka poety. Epistolograf dwukrotnie wspominał o niej w swojej korespondencji:

Donoszę ci, że mam córkę zdrową, rzeźwą, tłustą, której dałem imię Helena, ażebym ułatwił przyszłemu jej amantowi znalezienia rymu do jej imienia, i nastręczył naturalne porównanie jej wdzięków z wdziękami Heleny greckiej. Moja Józia karmi ją sama. I jest równie dla niej najczulszą matką, jak dla mnie najlepszą żoną. Nie odwołuję ja i teraz tego, com mówił zawsze o niebezpieczeństwach stanu małżeńskiego, i tem więcej cenię szczęśliwość mojego losu, który mi tylko samych słodyczy tego stanu kosztować pozwala. (list z 9 listopada 1801 roku z Horochowa, s. 398)

Wiedzcie przynajmniej tymczasem, żeśmy zdrowi, moja matka, siostra, żona, dwoje dzieci i ja. Córka ma już lat trzynaście, syn dwanaście. Córki ręką piąty akt Barbary przepisany, tobie posyłam. Oboje dzieci dotąd są dla nas rodziców pociechą: mają dobre serca i najlepsze skłonności. Córka ma dowcip, objęcie łatwe i prędkie, w moment się nauczy, lecz nie bardzo trwale; chłopiec jest powolniejszy w objęciu, ale gruntowniej, i na dłużej wszystkiego się uczy. (list z 20 sierpnia 1811 roku z Rafałówki, s. 402)

${ }^{32} \mathrm{Na}$ temat niezwykle życzliwej natury Tekli Felińskiej zob. wspomnienia E. Felińskiej (dz. cyt., s. 203-204, 200-201, 212-214). 
Mając zatem na uwadze stosunek poety do własnej córki, wypada podkreślić, że autor Barbary... prezentuje się Wyszkowskiemu jako zadowolony i kochający ojciec. Wraz z żoną sprawuje opiekę nad latoroślą, rezygnując tym samym z odpłatnej pomocy przy jej doglądaniu. Można wnioskować, że jego serdeczne relacje z dziewczynką wynikały z codziennego obcowania z dzieckiem. O wyjątkowości atmosfery dzieciństwa panującej w domu Felińskich decydowały zapewne inteligencja i wyczucie rodziców ${ }^{33}$.

Na szczególne podkreślenie zasługuje fakt, że poeta obiektywnie ocenia swoją latorośl. Aby powiadomić przyjaciela o urodzie córki, zwraca uwagę na nadane jej imię (Helenka). Pisząc natomiast o jej zdolnościach, podkreśla błyskotliwość dziewczynki. Ponadto odtwarza realia z otoczenia swoich pociech (na przykład karmienie piersią przez ich matkę czy informacje na temat zdrowia dzieci) ${ }^{34}$.

Te krótkie opisy świadczą o tym, jak znaczne zmiany zachodzą w wychowaniu potomstwa na początku wieku XIX ${ }^{35}$. Obserwuje się coraz częściej osobiste zaangażowanie rodziców w opiekę i edukację pociech, co w pewnym sensie należy uznać za konsekwencję reformy szkół pijarskich w połowie XVIII wieku, a z czasem kolejnych przemian w zakresie edukacji w Polsce. Zgodnie z myślą Johna Locke'a zwraca się także uwagę na intelektualny i fizyczny rozwój dziecka, a rodziców i nauczycieli obarcza tym samym odpowiedzialnością za kształtowanie młodych ludzi. Podkreśla się ponadto wagę i specyfikę dzieciństwa jako niezwykle istotnego etapu ludzkiego życia. Poddając się naukom Jana Jakuba Rousseau, dziecku nie odmawia się odtąd prawa do spontaniczności i radości, występuje przeciwko jego „tresurze” i nadaje mu się cywilizacyjną godnośćc ${ }^{36}$.

$$
* * *
$$

Życie gospodarza Osowy nie obfitowało w skandale, a biografia nie wymagała ocenzurowania. Przytrafiła mu się młodzieńcza niespełniona i nieszczęśliwa miłość (Zofia Załęska). U jego boku nie stanęła bratnia dusza, natchniona poetka, ale rozsądna i praktyczna kobieta, twardo stąpająca po ziemi, opiekunka domowego ogniska, z którą poeta pozostał aż do śmierci (Józefa Omiecińska). Pasje i zainteresowania literackie dzielił natomiast ze starszą siostrą, którą podziwiał za uro-

${ }^{33} \mathrm{Na}$ temat dzieci Felińskiego zob. też uwagi E. Felińskiej (dz. cyt., s. 213) oraz K.P. Kanteckiego (dz. cyt., s. 74).

${ }^{34} \mathrm{O}$ dzieciach Felińskiego pisałam również w artykule pt. Dziecko $w$ świetle prywatnej korespondencji oraz pism Alojzego Felińskiego, w: Dziecko - literatura, sztuka, język, red. R. Starz, Wydawnictwo Uniwersytetu Jana Kochanowskiego, Kielce 2016, s. 128-137.

${ }^{35} \mathrm{Na}$ temat pozycji, jaką zajmowało dziecko w dawnej Polsce zob. pracę Doroty Żołądź-Strzelczyk pt. Dziecko w dawnej Polsce, Wydawnictwo Poznańskie, Poznań 2006.

${ }^{36}$ Por. M. Nalepa, Oświeceniowe korzenie współczesności - wybrane zagadnienia na lekcjach języka polskiego, „Zeszyty Naukowe Uniwersytetu Rzeszowskiego” 2005. Seria Filologiczna. Dydaktyka, z. 32, s. 23-24. 
dę, usposobienie, a nade wszystko poetycki talent (Emilia z Felińskich Potocka). W końcu czuł się dumny, gdy został ojcem i mógł otoczyć troskliwą opieką swoją córkę, Helenkę Felińską.

Każda z zaprezentowanych kobiet odegrała szczególną rolę w życiu poety. Każdą darzył Feliński osobliwym rodzajem uczucia, adekwatnym dla łączącej go z nią relacji. Każdej w końcu odmalował własnym piórem niebanalny portret, często tworząc niejako kobiecy wzór żony, matki czy obywatelki na miarę XIX wieku. Wskazując na zupełnie prywatne epizody z ich życia, opisywał jednocześnie walory moralne i intelektualne prezentowanych dam. W pewnym stopniu każda z przedstawionych pań może być również przykładem osobowego wzoru będącego inspiracją dla zachowań społecznych innych kobiet żyjących w pierwszej połowie XIX stulecia ${ }^{37}$.

\section{Bibliografia}

\section{Podmiotowa}

Felińska Ewa, Pamiętniki z życia, t. 1, seria 2, Józef Zawadzki, Wilno 1858.

Feliński Alojzy, „Do Franciszka Wiśniowskiego”, w: tegoż, Pisma i listy Alojzego Felińskiego przepisane z jego autografów, rkps Ossol. 2097/I, k. 1-6.

Feliński Alojzy, Do Sofii, w: Pisma i listy Alojzego Felińskiego przepisane z jego autografów, rkps Ossol. 2097/I, k. 14-15.

Feliński Alojzy, Listy do Michała Wyszkowskiego, w: Klementyna z Tańskich Hoffmanowa, Dzieła. Wydanie nowe z dodaniem życiorysu i objaśnień, red. Narcyza Żmichowska, t. 6, Spółka Wydawnicza Księgarzy, Warszawa 1875, s. 392-415.

Feliński Alojzy, Szczęśliwe matżeństwo (przekład fragmentu Pór roku Jamesa Thomsona), w: tegoż, Pisma własne i przekładania wierszem, t. 1, Drukarnia Rządowa, Warszawa 1816, s. 369-371.

Turski Wincenty, Do cieniów Alojzego Felińskiego, „Weteran Poznański” 1825, nr 1 (luty), s. 57-61.

\section{Przedmiotowa}

Bibliografia Literatury Polskiej „Nowy Korbut”, oprac. E. Aleksandrowska z zespołem, t. 4: Oświecenie, A-H, Państwowy Instytut Wydawniczy, Warszawa 1966, s. 451-456, hasło: Feliński Alojzy.

Bibliografia Literatury Polskiej „,Nowy Korbut”, oprac. E. Aleksandrowska z zespołem, t. 6, cz. 1: Oświecenie, P-Ż, Państwowy Instytut Wydawniczy, Warszawa 1970, s. 434, hasło: Wiśniowski Franciszek Salezy.

Bilica Krzysztof, , Boże coś Polskę” Felińskiego-Kaszewskiego. Inspiracje i echa, w: tegoż, Wokót Chopina i Polski. Siedem szkiców, Wydawnictwo Polskie, Wołomin 2005, s. 30-59.

Dąbrowski Szymon Piotr, Rodzinne i środowiskowe uwarunkowania natury oraz losów Alberta Potockiego w świetle przekazów pamiętnikarskich, w: Sarmackie theatrum VII. W kręgu rodziny i prywatności, red. M. Jarczykowa, R. Ryba, Wydawnictwo Uniwersytetu Śląskiego, Katowice 2014, s. 238-252.

${ }^{37} \mathrm{Na}$ temat osobowych wzorów inspirujących pozytywnie waloryzowane zachowania społeczne zob. uwagi Barbary Wolskiej - Poezja pochwalna i panegiryczna Adama Naruszewicza. Pochwaty osobistości publicznych i osób prywatnych, w: Panegiryk jako element życia literackiego doby staropolskiej i oświeceniowej, red. M. Sulejewicz-Nowicka i Z. Gruszka, ze wstępem M. Wichowej, Wydawnictwo Uniwersytetu Łódzkiego, Łódź 2013, s. 176. 
Kantecki Klemens Piotr, Dwaj krzemieńczanie, cz. 1: Alojzy Feliński, Gubrynowicz i Schmidt, Lwów 1879, s. 1-157.

Karpiński Adam, Staropolska poezja ideałów ziemiańskich. Próba przekroju, Zakład Narodowy im. Ossolińskich, Wrocław 1983. Studia Staropolskie, t. 49.

Koźmian Kajetan, Pamiętniki, t. 3, przedm. A. Kopacz, wstęp i koment. J. Willaume, wstęp edytorski, ustalenie tekstu w oparciu o autograf oraz koment. filologiczny M. Kaczmarek, K. Pecold, Zakład Narodowy im. Ossolińskich, Wrocław 1972.

Omiecińska Józefa, List z 18 czerwca 1820 roku, pisany w Wolosowie do JJWW. Narcyza i Gustawa Graffów Olizarów, w: Alojzy Feliński, Pisma własne i przekładania wierszem, t. 2, Drukarnia Natana Glücksberga księgarza i typografa Królewskiego Uniwersytetu, Warszawa 1816-1821, s. [7-8].

Orgelbrand Samuel, Feliński Alojzy, w: Encyklopedia powszechna, t. 8, nakład, druk i własność Samuela Orgelbranda księgarza i typografa, Warszawa 1861, s. 727-728.

Orgelbrand Samuel, Wiśniowski Franciszek, w: Encyklopedia powszechna, t. 27, nakład, druk i własność Samuela Orgelbranda księgarza i typografa, Warszawa 1876, s. 264.

Nalepa Marek, Oświeceniowe korzenie współczesności - wybrane zagadnienia na lekcjach języka polskiego, „Zeszyty Naukowe Uniwersytetu Rzeszowskiego” 2005. Seria Filologiczna. Dydaktyka, z. 32, s. 9-25.

Patro-Kucab Magdalena, Ciag dalszy sporu o ,intruza gdańskiego”, czyli Alojzy Feliński ripostuje Janowi Śniadeckiemu (Rozmowa w Zaciszy z powodu listu Pana Szczeropolskiego), w: Kultura mówienia dawniej i dziś, red. M. Kułakowska, A. Myszka, Wydawnictwo Uniwersytetu Rzeszowskiego, Rzeszów 2014, s. 101-111.

Patro-Kucab Magdalena, Dziecko w świetle prywatnej korespondencji oraz pism Alojzego Felińskiego, w: Dziecko - literatura, sztuka, język, red. R. Starz, Wydawnictwo Uniwersytetu Jana Kochanowskiego, Kielce 2016, s. 128-137.

Patro-Kucab Magdalena, Kreacja wołyńsko-poleskiej przestrzeni (na podstawie listów Alojzego Felińskiego do przyjaciela, Michała Wyszkowskiego), w: Język polski i polonistyka w Europie Wschodniej: przeszłość i współczesność, Praca zbiorowa z okazji dziesięciolecia Katedry Filologii Polskiej Narodowego Uniwersytetu Lwowskiego im. Iwana Franki, red. I. Bundza, J. Kowalewski, A. Krawczuk, O. Śliwiński, Firma „INKOS”, Kijów 2015, s. 188-191.

Patro-Kucab Magdalena, Osowa Alojzego Felińskiego. Kreacja ziemiańskiego pejzażu w listach poety skierowanych do Michała Wyszkowskiego, w: Antropologia krajobrazu: obraz-zmysty-pamięć, red. B. Frydryczak, M. Ciesielski, Wydawnictwo Poznańskiego Towarzystwa Przyjaciół Nauk, Poznań 2014, s. 315-326, Seria Krajobrazy, t. 5.

Piotrowski Wojciech, Gustaw Olizar (1798-1865), w: Krzemieniec. Ateny Juliusza Słowackiego, red. S. Makowski, Wydawnictwo Biblioteki Narodowej, Warszawa 2004, s. 334-344.

Piotrowski Wojciech, Życie umysłowe Krzemieńca 1805-1832, Naukowe Wydawnictwo Piotrkowskie przy Filii Akademii Świętokrzyskiej, Piotrków Trybunalski 2005.

Ratajczakowa Dobrochna, Alojzy Feliński (1771-1820), w: Pisarze polskiego Oświecenia, red. T. Kostkiewiczowa, Z. Goliński, t. 3, Wydawnictwo Naukowe PWN, Warszawa 1996, s. $173-198$.

Sowiński Jan, O uczonych Polkach, w księgarniach Natana Glücksberga. Księgarza i typografa Uniwersytetu Warszawskiego i Liceum Wołyńskiego, Warszawa-Krzemieniec 1821, s. 157-165.

Stawiak-Ososińska Małgorzata, Ponętna, uległa, akuratna... Ideat i wizerunek kobiety polskiej pierwszej połowy XIX wieku (w świetle ówczesnych poradników), Wydawnictwo Impuls, Kraków 2010.

Wolska Barbara, Poezja pochwalna i panegiryczna Adama Naruszewicza. Pochwaty osobistości publicznych i osób prywatnych, w: Panegiryk jako element życia literackiego doby staropolskiej i oświeceniowej, red. M. Sulejewicz-Nowicka, Z. Gruszka, ze wstępem M. Wichowej, Wydawnictwo Uniwersytetu Łódzkiego, Łódź 2013, s. 165-206. 
Wyszkowski Michał, Przymówienie się Referendarza Stanu Michała Wyszkowskiego na posiedzeniu publicznem dnia 3 Maja 1820 r. przed rozpoczęciem czytania przez Niego wyimków $z$ „Poezyi” zmartego niedawno Kolegi Alojzego Felińskiego, „Roczniki Towarzystwa Królewskiego Warszawskiego Przyjaciół Nauk" 1821, t. 14, s. 124-127.

Żołądź-Strzelczyk Dorota, Dziecko w dawnej Polsce, Wydawnictwo Poznańskie, Poznań 2006.

\section{Magdalena Patro-Kucab}

\section{Women in the life and work of Alojzy Feliński}

\section{(Summary)}

The authors of papers dedicated to Alojzy Feliński, while reaching for his works, analyzed above all his Barbara Radziwiłtówna or Hymn na rocznicęogłoszenia Królestwa Polskiego... Unfortunately, there are no broader discussions of Feliński's relationships with women within research interests, despite the fact that many episodes addressed to them can be found in the playwright's work.

In the exemplification, the author of the article examines fragments of letters, diaries and poems relating to women who played a special role in the playwright's life.

The purpose of the thesis is not to reveal completely unknown works or events from Feliński's biography to the reader. The research point of view is primarily an attempt to gather in one publication the works of the Radamist $i$ Zenobia's author dealing with the women whom the artist met in his life and to whom he did not remain indifferent. These included, among others: Zofia Załęska, Józefa Omiecińska, Emilia and Tekla from the Feliński family and Helena Felińska. The topic seems interesting and definitely deserves wider recognition, because it will present the representative of postanisławowski classicism in a broader and more comprehensive light, yet far from inducing any sensation.

Keywords: woman in the Enlightenment; Feliński and women; love life of Feliński; Feliński as a brother and father

Słowa kluczowe: kobieta w oświeceniu; Feliński i kobiety; życie intymne Felińskiego; Feliński w roli brata i ojca 